\title{
IMPACT OF COMPANY PERFORMANCES ON THE STOCK PRICE: AN EMPIRICAL ANALYSIS ON SELECT COMPANIES IN SERBIA
}

\author{
Snežana Milošević Avdalović1, Ivan Milenković
}

\begin{abstract}
Summary
The global financial crisis of the late 2007 has provoked unprecedented shocks to the world markets and weaken investors' confidence due to the turbulent movements and frequent changes of stock prices. Emerging capital markets suffer from unsatisfactory corporate governance, market manipulation and insider trade problems. In such circumstances, institutional investors, managers, analysts and other market participants are in constant search of the trading strategy that will outperform the market. This research is an instrument for the identification of the main determinants of stock prices on the Belgrade Stock Exchange. The panel data regression analysis includes 42 companies that represent the composition of the BelexLine index for the period from 2010 to 2014. The paper looks at the impact of specific (internal) variables of companies, such as company size, return on assets, return on equity, earnings per stock, book value, price-earning ratio, price-to-book ratio and leverage and the stock price of companies that compose the BelexLine index. The results indicate that variables such as the size of the company measured by assets, return on assets, leverage, earnings per stock, book value and price-to-book ratio provide a unique contribution to a statistically significant predictor of stock prices.
\end{abstract}

Key words: company performances, stock prices, regression analysis

JEL: C32, G14, L11, N50, Q11

\section{Introduction}

Economists make us believe that the price of securities is affected by supply and demand in a free economy. Even if we accept this attitude of economists, the question is what factors determine the supply and demand? Whether it comes to price? Yes,

1 Snežana Milošević Avdalović, Teaching Assistant, University of Novi Sad, Faculty of Economics Subotica, Segedinski put no. 9-11, 24000 Subotica, Republic of Serbia, E-mail: smilosevic@ef.uns.ac.rs

2 Ivan Milenković Ph.D., Associate Professor, University of Novi Sad, Faculty of Economics Subotica, Segedinski put no. 9-11, 24000 Subotica, Republic of Serbia, E-mail: imilenkovic@ef.uns.ac.rs

EP 2017 (64) 2 (561-570) 
but not all the time, there are other important factors. Pricing of the stock market is significantly affected by the dividend per stock, earnings per stock, price-to-earning ratio and dividend payout (Gompers, Ishii, Metrick, 2003).

Government policy, company operation and performances as well as various industries influence the behavior of investors, both in the primary and secondary capital markets. Policy makers who are concerned about the growth of capital markets need to be better informed on how to activate the instruments of monetary policy, as well as other economic indicators in order to reach the desired growth and development. In developing countries, such as Serbia, the stock market can stimulate economic growth by enabling companies to raise capital at lower prices (Milanović et al., 2017). Stock markets perform a key function in providing the necessary critical links between companies that need funds to start new businesses or to expand their current operations and investors who have surplus funds to invest in such companies. In addition, countries with emerging capital markets depend on bank financing, which may increase credit risk. Therefore, there is a paramount importance, but also the need to study and develop capital markets in order to strengthen alternative sources of financing. Encouraging investments and managing political risks are crucial for the development of stock markets in emerging economies, as well as for investment decisions (Andžić et al., 2016). Factors that influence the stock prices are numerous and inexhaustible, and can be classified as micro-economic (internal) and macroeconomic (external) factors.

\section{Literature Review}

In the spirit of this project, Khan et al (2011) analyzed 55 companies that are listed on the Karachi Stock Exchange, in the period from 2001-2010. years. The results indicate that the dividend, earnings per stock, return on equity and net profit positively correlate with stock prices, while retention ratio has a negative effect on stock prices and significantly explains stock prices variations on the stock exchange. Another significant and positive determinant of stock prices that appeared in studies conducted by Balkrishnan (1984), Zahir and Khanna (1982) and Sharma (2011) was the book value of stocks. These studies indicate that a specific internal factors have a significant impact on the market price of the stocks.

Sharif, Purohit and Pillai (2015) investigated the determinants of stock price of 41 companies listed on the Bahrain Stock Exchange. The empirical findings reveal a positive and significant relationship between return on eqity, book value per stock, ratio dividend paid and number of stock outstanding, ratio stock price and earning per stock and market capitalization, suggesting that these factors act as active determinants in shaping the market price of stocks. However a significant negative relationship was found between dividend yield and stock price. This suggests that dividend decisions are made in order to attract different clienteles. Consistencies in results have been noticed in both the estimation models. Therefore, a certain group who expects short term and regular return will show their impact as a positive relationship with market price while the group who is unaffected or considers dividends as irrelevant will show an 
inverse relationship with stock price. Leverage also showed an inverse but insignificant relationship with market price. This can be due to the fact that investors show a general aversion towards heavily indebted companies but at the same time do not consider the inclusion of debt in the capital structure of companies as a determinant of market price.

Al Shubiri, F.N. (2010) studied the impact of macroeconomic and institutional determinants of stock market development in developing countries, using panel data analysis of 14 banks in the period from 2005 to 2008. Regression analysis was applied during the processing of secondary data from banks on the Amman Stock Exchange in Jordan. The study showed a significant positive correlation between the market stock price and net asset value per stock, dividend yield and gross domestic product, while the negative relationship was established between the market stock price and inflation, as well as the market stock price and interest rates on loans.

Irfan and Nishat (2002) analysed the impact of six variables - dividends, payment ratio, company size, asset growth, leverage and return on assets on the stock price at the Karachi Stock Exchange in Pakistan in the period from 1981 to 2000. Panel data regression analysis used annual data in the financial statements of companies as a survey sample. They found that the payment ratio, company size and dividend yield are important factors in the stock price.

Uddin et al (2013) investigated the impact of net asset value, earnings per stock, profit after tax and price-earnings ratio of 72 companies in the financial sector in Bangladesh during the period from 2005 to 2010 by using descriptive statistics and regression analysis. The study found out that the earnings per stock and net asset value are strong stock price determinants in all years, and showed a statistically significant positive relationship with stock prices. There was a positive but statistically insignificant relationship between net income, price-earnings ratio and stock price.

\section{Methodology}

The table below provides an overview of the financial company performances that were analysed as stock price determinants. In the column Impact on the stock price a positive or negative effect of observed independent variables on the dependent variable was assumed. The independent indicators were selected with regard to previously conducted research of many authors on this topic.

$\mathrm{SP}=\alpha+\beta_{1}$ Assets $+\beta_{2} \mathrm{ROE}+\beta_{3} \mathrm{ROA}+\beta_{4} \mathrm{EPS}+\beta_{5} \mathrm{BV}+\beta_{6} \mathrm{LEV}+\beta_{7} \mathrm{P} / \mathrm{E}+\beta_{8} \mathrm{P} / \mathrm{B}+\delta_{i}+\varepsilon_{i t}$ where:

SP - Stock price

$\alpha-$ constant

$\beta$-coefficient which represents the slope of variables

$\delta$ - represents fixed effects on the Belgrade stock exchange

ci - means the error term

EP 2017 (64) 2 (561-570) 
Table 1. Variables definition

\begin{tabular}{|l|c|c|}
\hline Variables: & Symbol & $\begin{array}{c}\text { Expected impact on the stock } \\
\text { price }\end{array}$ \\
\hline Independent variables & Assets & - \\
\hline Total assets of the company & ROE & + \\
\hline Return on equity & ROA & + \\
\hline Return on assets & EPS & + \\
\hline Ernings per stock & BV & + \\
\hline Book value & LEV & + \\
\hline Leverage & P/E & + \\
\hline Price-earnings ratio & P/B & + \\
\hline Price-to-book ratio & & \\
\hline Dependent variable & SP & \\
\hline $\begin{array}{l}\text { Stock price at closing at the end of the financial } \\
\text { year, i.e. 31.12. of the observed year }\end{array}$ & & \\
\hline
\end{tabular}

Source: Review authors

Company size can be measured in several ways. In this paper, the total assets of the company expressed as the natural logarithm was used as measure. It is believed that large companies can offer better investment opportunities than smaller companies to investors. Canbas et al. (2007) examined the relationship between the characteristics of the company and the stock price. They noted that the ordinary stocks of small companies, have a higher yield than the ordinary stocks of large companies. Therefore, a negative relationship between the company size and the stock price is assumed which also represents one of the capital market anomalies. Well known anomalies of small companies, according to which small companies realize a higher yield per stock is in contradiction with the capital market efficiency hypothesis. The existence of the size effect casts serious doubts on the level of the capital market efficiency.

Furthermore, it is assumed that there is a positive relationship between company profitability and stock prices. Profitability is measured by return on assets, return on equity and earnings per stock. The increase in profitability increases the market price of the stocks.

The book value of stocks represents a good picture of company performance because it indicates the value of the company. Therefore it is expected that the growth of this indicator leads to the growth of stock prices on the stock exchange.

Canbas et al. (2007) also noted that there is a positive relationship between leverage and stock price. They found that companies with high leverage have higher yields in relation to companies with low leverage. The theoretical stance, according to which the risk requires a fee, confirms this view. 
It is assumed that there is also a positive relationship between stock prices and priceearnings ratio. Generally, high $\mathrm{P} / \mathrm{E}$ indicator suggests that investors are expecting higher earnings growth in the future than companies with lower $\mathrm{P} / \mathrm{E}$ ratio. Price-to-book ratio is positively correlated with the stock price of the company.

Due to changes in the stock price from minute to minute it becomes complicated to decide which price should be taken as a measure of the dependent variable. In this paper, the stock price at closing at the end of the financial year, i.e. 31.12. of the observed year, was taken as a dependent variable.

Based on the objectives of research, onethe null and the alternative hypothesis can be defined.

HO - there is significant effect of observed variables (company performances) on the market price for stocks of companies at the Belgrade Stock Exchange

H1 - the observed variables (company performance) do not contribute to changes in the stock price, that is, there is no significant correlation between the observed independent variables and the stock prices.

Data for the study were obtained from the website of the Belgrade Stock Exchange and available financial statements of the Serbian Business Registers Agency. The companies selected for empirical research belong to the following sectors represented in the table below:

Table 2.Overview of sectors and the number of companies covered by research

\begin{tabular}{|l|c|}
\hline Sectors & No. \\
\hline A - Agriculture, forestry and fishing & 2 \\
\hline B - Mining & 1 \\
\hline C - Processing industry & 18 \\
\hline F - Construction & 4 \\
\hline G - Wholesale and retail trade and repair of motor vehicles & 1 \\
\hline H - Transportation and Warehouse & 2 \\
\hline K - Financial and insurance activities & 10 \\
\hline L - Real estate & 1 \\
\hline M - Professional, scientific and innovative technology activities & 2 \\
\hline P - Education & 1 \\
\hline
\end{tabular}

Source: Authors

Figure 1 presents the average price of stock for the observed sector in the period from 2010 to 2014 . 
Figure 1.Average price of stocks

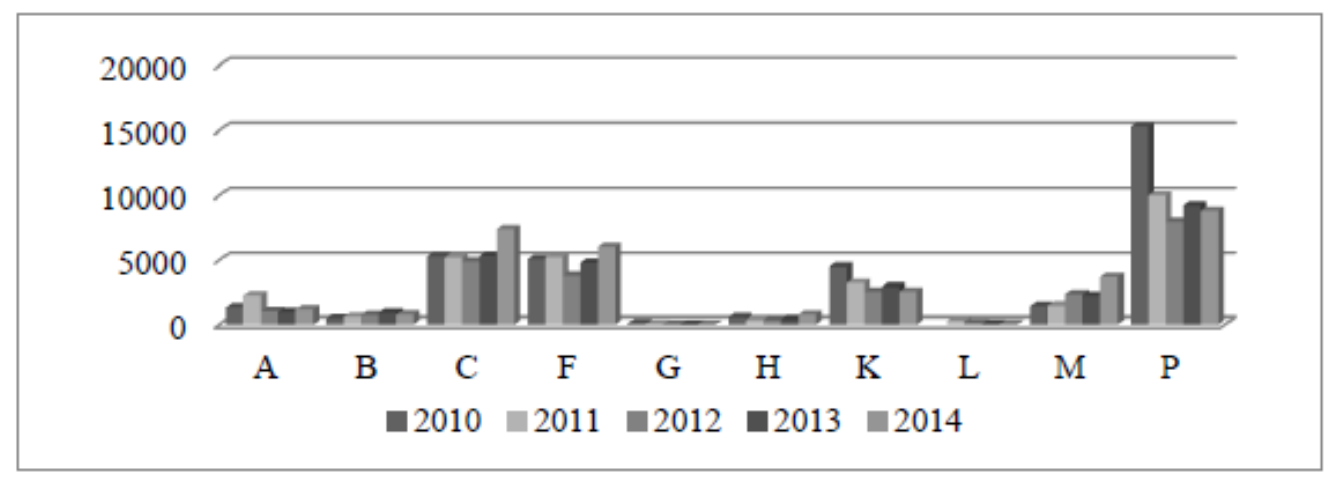

Source: Author's illustration (based on data from the Belgrade Stock Exchange)

\section{Empirical research}

The correlation between independent variables and the dependent variable - the stock price was calculated from 209 samples. Preliminary analysis were conducted in order to prove that the assumptions about normality, homogeneity and linearity of variance were satisfied. Pearson Correlation was used to investigate links within the entire group of variables. There is high correlation between the market price and the book value of stocks. Medium degree of correlation exists between the market price of stocks and return on equity, return on assets and the price-to-book ratio, while statistically significant but low degree of correlation exists between the market price of stocks and earnings per stock. The high degree of correlation indicates that the variance of the observed market price of stocks is explained $28.20 \%$ by book value of stocks, $23.23 \%$ by return on assets, $10.5 \%$ by return on equity, $9.67 \%$ by price-to book ratio and $5.90 \%$ by earnings per stock.

Table 3. Correlation of variables

\begin{tabular}{|l|l|c|c|c|c|c|c|c|c|c|}
\hline \multicolumn{2}{|c|}{} & SP & Assets & ROE & ROA & LEV & EPS & BV & P/E & P/B \\
\hline \multirow{3}{*}{ SP } & $\begin{array}{l}\text { Pearson } \\
\text { Correlation }\end{array}$ & 1 & -.023 & $\mathbf{. 3 1 7 ^ { * * }}$ & $\mathbf{. 4 8 3}$ & .032 & $\mathbf{. 2 4 3}^{* *}$ & $\mathbf{. 5 3 1} 1^{* *}$ & -.021 & $\mathbf{. 3 1 1}^{* *}$ \\
\cline { 2 - 10 } & $\begin{array}{l}\text { Sig. } \\
\text { (2-tailed) }\end{array}$ & & .736 & $\mathbf{. 0 0 0}$ & $\mathbf{. 0 0 0}$ & .645 & $\mathbf{. 0 0 0}$ & $\mathbf{. 0 0 0}$ & .762 & $\mathbf{. 0 0 0}$ \\
\cline { 2 - 10 } & N & 209 & 209 & 209 & 209 & 209 & 209 & 209 & 209 & 209 \\
\hline
\end{tabular}

Source: Author's calculations, SPSS output

The coefficient of determination is 0.562 , which indicates that $56.20 \%$ of the variance of the dependent variable is explained by the applied model (see Table 4). 
Table 4. Model Summary

\begin{tabular}{|c|c|c|c|c|}
\hline Model & R & R Square & $\begin{array}{c}\text { Adjusted R } \\
\text { Square }\end{array}$ & $\begin{array}{c}\text { Std. Error of the } \\
\text { Estimate }\end{array}$ \\
\hline 1 & $.750^{\mathrm{a}}$ & .562 & .545 & .430556866 \\
\hline
\end{tabular}

Source: Author's calculations, SPSS output

Table 5. presents an analysis of variance. Good multiple regression model indicates a high value of $F$ value (32.106) and the very low level of significance of F-values (.000). Statistical significance indicator model is tested by the null hypothesis which is below the $\mathrm{p}<0.05$ and proves statistical significance of the model.

Table 5. ANOVA - analysis of variance

\begin{tabular}{|l|l|c|c|c|c|c|}
\hline \multicolumn{2}{|c|}{} & $\begin{array}{c}\text { Sum of } \\
\text { Squares }\end{array}$ & Df & Mean Square & F & Sig. \\
\hline \multirow{2}{*}{1} & Regression & 47.615 & 8 & 5.952 & 32.106 & $.000^{\mathrm{b}}$ \\
\cline { 2 - 7 } & Residual & 37.076 & 200 & .185 & & \\
\cline { 2 - 7 } & Total & 84.691 & 208 & & & \\
\hline
\end{tabular}

Source: Author's calculations, SPSS output

VIF test is conducted in the analysis in order to investigate the presence/absence of collinearity among independent variables. Since all values were below the critical value of 10 , there was no multi-collinearity which indicates that the model is good.

Presented coefficients in the table 6 . indicate the direction of the relationship between independent variables and the dependent variable on the BSE. These coefficients tell us the extent to which variable affects the outcome with assumption that the effects of all other variables are constant. Signs of all independent variables are in line with theoretical assumptions. To compare the contribution of all independent beta coefficient was used (standardized coefficient), which means that the values of all variables were converted to the same scale so that they can be compared. By comparing the absolute values, following variables have statistically significant influence according to their intensity: book value $(+)$, return on assets $(+)$ price-to-book ratio $(+)$ leverage $(+)$, earnings per stock (-), company size (-), while return on equity and price-earnings ratio have no significant impact on the individual price movements on the stock exchange in Belgrade, but contribute to the overall model. 
Table 6.Impact of selected company performances on the stock price

\begin{tabular}{|c|c|c|c|c|c|c|c|c|}
\hline & \multirow[t]{2}{*}{ Model } & \multicolumn{2}{|c|}{$\begin{array}{c}\text { Unstandardized } \\
\text { Coefficients } \\
\end{array}$} & \multirow{2}{*}{$\begin{array}{c}\begin{array}{c}\text { Standardized } \\
\text { Coefficients }\end{array} \\
\text { Beta }\end{array}$} & \multirow{2}{*}{$\mathbf{T}$} & \multirow{2}{*}{ Sig. } & \multicolumn{2}{|c|}{$\begin{array}{c}\text { Collinearity } \\
\text { Statistics }\end{array}$} \\
\hline & & B & $\begin{array}{l}\text { Std. } \\
\text { Error }\end{array}$ & & & & Tolerance & VIF \\
\hline \multirow{9}{*}{1} & (Constant) & 2.100 & .324 & & 6.483 & .000 & & \\
\hline & Assets & -.142 & .047 & -.158 & -3.034 & .003 & .810 & 1.234 \\
\hline & ROE & -.001 & .002 & -.030 & -.388 & .698 & .378 & 2.643 \\
\hline & ROA & .028 & .005 & .460 & 5.293 & .000 & .289 & 3.456 \\
\hline & LEV & .007 & .001 & .271 & 4.801 & .000 & .689 & 1.451 \\
\hline & EPS & .000 & .000 & -.231 & -3.735 & .000 & .573 & 1.744 \\
\hline & $\mathrm{BV}$ & .450 & .044 & .573 & 10.232 & .000 & .697 & 1.435 \\
\hline & $\mathrm{P} / \mathrm{E}$ & .000 & .000 & .037 & .767 & .444 & .965 & 1.037 \\
\hline & $\mathrm{P} / \mathrm{B}$ & .190 & .033 & .288 & 5.765 & .000 & .875 & 1.143 \\
\hline
\end{tabular}

Source: Author's calculations, SPSS output

By analysing the contribution of independent variables in the model and observing the beta coefficient can be concluded that the greatest contribution of 0.573 has book value of stocks. Return on assets has a little bit lower beta coefficient (0.460). Yet smaller, but statistically significant contribution has a price-to-book ratio $(0.288)$, leverage (0.271), earnings per stock (-0.231) and company size (-0.158). In the observed model, assets, return on assets, leverage, earnings per stock, book value and price-to-book ratio provide a unique contribution to a statistically significant predictor of stock prices.

\section{Conclusion}

To sum up, this study empirically examines the relationship between the observed company performances, such as company size, return on assets, return on equity, earnings per stock, the book value of stocks, leverage, price-earnings ratio, price-to-book ratio, book value per stock and the price of stocks of companies listed on the Belgrade Stock Exchange in the period from 2010 to 2014. Correlation and regression analysis of accounting information and stock prices indicate that the accounting information have an impact on stock prices, but the character is different. Accounting information about the book price of stocks and return on assets are the most significant. Based on the empirical experiment the null hypothesis can be accepted, that is, we can confirm the existence of statistically significant link between company performances and market stock price. Multiple regression indicates that all performances, with the exception of return on assets and price-earning ratio have a significant impact on changes in stock prices, although the return on assets is in correlation with the movement of the stock price. In conclusion, this study suggests that it is advisable for investors to know the determinants of stock prices when making investment decisions if they want to be sure of a fair return that they expect. 


\section{References}

1. Al-Shubiri, F.N. (2010): Analysis the Determinants of Market Stock Price Movements: An Empirical Study of Jordanian Commercial Banks, International Journal of Business and Management Vol. 5, No. 10, pp. 137-147

2. Andžić, S., Rajković, M., Ćosić, M. (2016): Nefinansijski aspekti poslovanja kao faktori razvoja preduzetništva, Oditor, Belgrade, Serbia, Vol. 2, No. 2, pp. 7-17.

3. Balakrishnan, K.P. (1984): Determinants of Equity Prices in India, Management Accountant, Vol. 19, No. 12, pp. 728-730

4. Irfan, C.M., Nishat, M. (2002): Key Fundamental Factors and Long-run Price Changes in an Emerging Market - A Case Study of Karachi Stock Exchange (KSE), The Pakisatn Development Review, Vol. 41, No. 4, Part II, pp.517-533

5. Khan, K. I., Aamir, M., Qayyum, A., Nasir, A., Khan, M. I. (2011): Can dividend decisions affect the stock prices: A case of dividend paying companies of KSE. International Research Journal of Finance and Economics, Vol. 76, No. 68, pp. 69-74.

6. Khan, KI. (2012): Effect of Dividends on Stock Prices - A Case of Chemical and Pharmaceutical Industry of Pakistan, Management, Vol. 2, No. 5, pp. 141-148.

7. Khan, M.N. (2012): Determinants of share prices at Karachi stock exchange, International Journal of Business and Management studies, Vol. 4, No. 1, pp. 111-120

8. Kiran,C., Chalam, G.V. (2015): Financial determinants of equity share prices: An empirical analysis study with reference to selected companies listed on Bombay Stock Exchange, International Journal Applied Financial Management Perspectives, Vol. 4, No. 2 , pp. 1761-1769

9. Kiran,C., Chalam, G.V. (2015): Equity share price determinants - An empirical analysis (An Empirical Analysis on select Steel Companies in India), Indian Journal of applied research, Vol. 5, No. 1, pp. 79-83

10. Milanović, N., Andžić, S., Butulija, M. (2017): Struktura kapitala kao determinanta vrednosti preduzeća, Oditor, Belgrade, Serbia, Vol. 3, No. 1, pp. 80-90.

11. Milošević Avdalović, S. (2015): Determinante cene akcija na Beogradskoj berzi, Zbornik radova XXI Internacionalni naučni skup SM, Strategijski menadžment i sistemi podrške odlučivanju, 20. maj, Palić, Ekonomski fakultet u Subotici, pp. 133-140.

12. Sharif, T., Purohit, H., Pillai, R. (2015): Analysis of Factors Affecting Share Prices: The Case of Bahrain Stock Exchange, International Journal of Economics and Finance, Vol. 7, No. 3, pp. 207-216

13. Sharma, S. (2011): Determinants of Equity Share Prices in India. Journal of Arts, Science and Commerce, Vol. 2, No. 4, pp.51-60

14.Uddin, R., Rahman, Z., Hossain, R. (2013): Determinants of Stock Prices in Financial Sector Companies in Bangladesh - A Study on Dhaka Sock Exchange (DSE), Interdisciplinary Journal of Contemprorary Research in Business, Vol. 5, No. 3, pp. 471-480

15. Vazakidis, A., Athianos, S. (2010): Do Dividend Announcements Affect The Stock Prices 
in The Greek Stock Market?, International Journal of Economic Sciences and Applied Research, Vol. 3, No. 2, pp. 57-77

16.Zahir, M.A., Khanna, Y. (1982): Determinants of Stock Prices in India, The Chartered Accountant, Vol. 30, No. 8, pp. 521-523

\title{
UTICAJ PERFORMANSI KOMPANIJA NA CENE AKCIJA: EMPIRJSKA ANALIZA NA ODABRANIM KOMPANIJAMA U SRBIJI
}

\author{
Snežana Milošević Avdalovičc ${ }^{3}$ Ivan Milenkovićc
}

\begin{abstract}
Apstrakt
Globalna finansijska kriza krajem 2007. godine izazavala je, bez presedana, potrese na svetskim berzama i poljulala poverenje investitora zbog burnih kretanja i čestih promena cena akcija. Tržišta kapitala u razvoju pate od nezadovoljavajućeg korporativnog upravljanja, manipulacija na tržištu i problema insajder trgovina. U takvim uslovima, institucionalni investitori, menadžeri, analitičari i ostali učesnici na tržištu, u stalnoj su potrazi za strategijom trgovanja koja će nadmašiti tržište. Ovo istraživanje predstavlja instrument za identifikaciju glavnih odrednica cena akcija na Beogradskoj berzi. Panel podataka regresione analize obuhvata 42 kompanije koje predstavljaju kompoziciju indeksa BelexLine za period od 2010. do 2014. godine. U radu se posmatra uticaj specifičnih (internih) varijabli preduzeća,kao što su, veličina preduzeća, prinos na aktivu, prinos na kapital, zarada po akciji, knjigovodstvena vrednost akcija, racio cena akcija i zarada po akciji, racio cena akcija i knjigovodstvene vrednosti akcija i leveridž i cena akcija preduzeća koja komponuju berzanski indeks BelexLine. Rezultati ukazuju da varijable kso što su veličina preduzeća merena aktivom, prinos na aktivu, leveridž, zarada po akciji, knjigovodstvena vrednost i racio cene i knjigovodstvene vrednosti po akciji daju jedinstveni statistički značajan doprinos predikciji cena akcija.
\end{abstract}

Ključne reči: performanse kompanija, cena akcija, regresiona analiza

3 Snežana Milošević Avdalović, Asistent,Univerzitet u Novom Sadu, Ekonomski fakultet u Subotici, Segedinski put br. 9-11, 24000 Subotica, Republika Srbija, E-mail: smilosevic@ef.uns.ac.rs

4 Vanredni profesor, dr Ivan Milenković, Univerzitet u Novom Sadu, Ekonomski fakultet u Subotici, Segedinski put br. 9-11, 24000 Subotica, Republika Srbija, E-mail: imilenkovic@ef.uns.ac.rs 